\title{
Hymenaea parvifolia Huber: dormancy breaking, morphology of fruit, seed and seedling ${ }^{1}$
}

\author{
Olivia Domingues Ribeiro ${ }^{*}$ D, Eniel David Cruz ${ }^{3}$, Mônica Falcão da Silva ${ }^{2}$, Betânia de Aviz Chaves ${ }^{4}$, \\ Olinda Maria Domingues Ribeiro ${ }^{4}$, Ely Simone Cajueiro Gurgel ${ }^{2}$
}

10.1590/0034-737X202168020003

\begin{abstract}
The successful use of native species in conservation actions depends on basic knowledge of their biology, beginning with the identification of regenerating individuals in the field, up to the behavior and development of the species from the early stages of germination. Moreover, seed propagation and germination may be limited by the occurrence of dormancy. The objective of this work was to identify the best method to overcome seed dormancy of Hymenaea parvifolia Huber, besides characterizing the fruits, seeds, post-seminal development and seedlings of naturally occurring specimens in Amazonia. For this, (i) tests for the breakdown of dormancy were performed through thermal, chemical and mechanical treatments; (ii) analyses of their effects on seed germination were made; and (iii) morphology of germinative development of Hymenaea parvifolia was described. The treatments based on sulfuric acid for 15, 25 and 35 minutes were the most efficient in overcoming the integumentary dormancy. However, scarification by grinding is recommended because it had been less impact on the environment. External characteristics and shape of the fruit, seed and epicotyl can aid taxonomy of the genus and identification of its species in the field. In addition, morphological characters of the fruit, seed, germination and seedling were illustrated.
\end{abstract}

Keywords: Amazonia; post-seminal development; scarification; sulfuric acid.

\section{INTRODUCTION}

Hymenaea parvifolia Huber (jutaí-mirim) belongs to the family Fabaceae, subfamily Detarioideae and tribe Detarieae (LPWG, 2017). Is a tree native to the Amazon basin, which occurs mainly in drier areas of the central part of Brazil and the eastern Amazon region (Silva et al., 2007; Pinto et al., 2018).It also occurs in coastal areas of the Brazilian states of Piauí and Maranhão and in the northeast of Pará state. It is commonly an emergent tree found in "terra firme" forest on sandy soils, but also occurs to a lesser extent in secondary forests (capoeira), or in grasslands (Langenheim \& Lee, 1974). The importance of this species for local riverine human populations can be found inits diverse array of uses, such as human and animal food, medicines and timber (Shanley \& Rosa, 2004).

Alongside direct extractivist uses, Hymenaea L. species are commonly recommended to support of the production of goods and services in degraded areas, such as live fences, shading of perennial and animal crops, forage production, green manure, among others (Miranda \& Valentin, 2000). However, the lack of scientific knowledge about the behavior and development of native species for reforestation and recovery of degraded areas underscores the need for fundamental studies on the biology of such species, so that they can be successfully

\footnotetext{
Submitted on September $16^{\text {th }}, 2019$ and accepted on November $9^{\text {th }}, 2020$.

'Extracted from the conclusion work of PIBIC scholarship by the first author. Work financed by CNPq. ${ }^{2}$ Museu Paraense Emílio Goeldi - Departamento de Botânica, Belém, Pará, Brazil. olivia_dr83@yahoo.com.br; esgurgel@museu-goeldi.br; monikafs@msn.com

${ }^{3}$ Embrapa Amazônia Oriental, Laboratório de Propagação de Plantas, Belém, Pará, Brazil. eniel.cruz@embrapa.br

${ }^{4}$ Universidade Federal Rural da Amazônia - UFRA, Belém, Pará, Brazil. thaniachaves10@hotmail.com; olinda-ribeiro@bol.com.br

'Corresponding author: olivia_dr83@yahoo.com.br
} 
used in biodiversity management and conservation plans (Tonini et al., 2008; Maranho et al., 2013). In addition, the phenotypic characteristics of seeds, of post-seminal development and young plant are attributes that can facilitate a more precise identification of the species (Oliveira, 2001), and alongside morphological knowledge of the vegetative and reproductive structures classically used in taxonomy, can help in the taxonomic problems and phylogenetic impasses that the traditional analysis of vegetative and floral organs alone cannot resolve (Gurgel et al., 2012). For example, Almeida et al. (2011) concluded that the morphological characteristics of the jatobá (Hymenaea) fruits and seeds can be used to support taxonomic studies of the genus, to help interpret germination tests carried out in the laboratory and to contribute to clarify their propagation methods. However, little is known about the morphological aspects of the fruit, seed and post-seminal development of the Hymenaea species, which featured in the studies of Botelho et al. (2000); Cruz et al. (2001); Melo et al. (2004) and BentesGama et al. (2008).

Additionally, the propagation of Hymenaea species may be limited by the occurrence of seed dormancy, delaying their germination. Cruz et al. (2001) detected germination of less than $20 \%$ in non-scarified seeds of Hymenaea intermedia Ducke. Andrade et al. (2010) also verified the impermeability of the tegument in Hymenaea courbaril L., with only $3.8 \%$ of germination when seeds were not submitted to any treatment to overcome dormancy. According to Fowler \& Bianchetti (2000), the seeds forehead of some Fabaceae genera presents layers of osteosclereides, a tissue layer which prevents the entry of water and can delay germination for several years. The literature suggests methods for overcoming this integumentary (or exogenous) dormancy, such as acid scarification, immersion in hot or cold water, and mechanical scarification (Carpanezzi \& Marques, 1981; Fowler \& Bianchetti, 2000; Azeredo et al., 2003; BentesGama et al., 2008; Mendes et al., 2016). However, no systematic and comparative study has been performed so far to safely identify effective methods for the dormancy breakdown of Hymenaea seeds that provides high vigor and germination.

Thus, the aim of the present study was to answer the following questions: i) What is the best method to break seed dormancy of $H$. parvifolia? ii) Can fruit, seed and seedling morphology of $H$. parvifolia help in the taxonomy of Hymenaea? For this, seed dormancy tests were carried out with $H$. parvifolia seeds scarified and the characterization of morphological aspects of the fruit, seeds and seedlings to help the identification of regenerating individuals in the field and conservation strategies.

\section{MATERIALAND METHODS}

The study was conducted at Embrapa Amazônia Oriental, Belém, Pará, Brazil. The seeds were obtained from fruits fallen naturally from the treetops and collected directly from the ground, at the Campo Experimental da Embrapa, in Mojú, Pará, Brazil (0209’38,8 “'S, 4847’ 56,2" W).

The efficiency in the dormancy breaking of $H$. parvifolia seeds was evaluated for the following treatments: scarification in PA sulfuric acid for $15 \mathrm{~min}, 25$ min and $35 \mathrm{~min}$; scarification with an abrasive surface (electric grinder, $3450 \mathrm{rpm}$ ) on the side (near the hilum) and distal region (opposite the hilum) of the seed; scarification in hot water $\left(70^{\circ} \mathrm{C}\right)$ for $30 \mathrm{~min}$; and immersion in distilled water for 48 hours. These treatments were compared to a control treatment (non-scarified seeds). For the treatment with sulfuric acid, $250 \mathrm{~mL}$ of acid was used for 110 seeds and after scarification the seeds were washed under running water for 10 minutes to remove the acid from the seed coat.After application of the treatments, the seeds were dried with paper towel and later sown at $1.0 \mathrm{~cm}$ depth. The sowing containers were made of polypropylene, with $12.5 \mathrm{~cm}$ (diameter) x $45.5 \mathrm{~cm}$ (depth), containing sand substrate and cured sawdust (1:1) boiled in water for two hours. Irrigation was done every two days during the experiment (20 days).

The number of days to initial seedling emergence (ISE) and number of emerged seedlings (ES) were counted each day. The final percentage of emerged seedlings was determined 20 days after the seeds were sown. Seedlings were considered emerged when all of their cotyledonswere above the substrate surface. At the end of the experiment, the substrate was washed and the percentages of emergence (E), hard seeds (HS - seeds that did not absorb water and, at the end of experiment, looked the same as when planted), dormant seeds (DS - viable seeds that absorbed water and were swollen, but did not germinate during the experiment), dead seeds (DS) and abnormal seedlings (AS) were determined. The seedling emergence speed index (SEI) was also determined based on the procedure used by Maguire (1962). Emergence was represented by the normal seedlings, according to Brasil (2009). For the vigor test, the biometric data of hypocotyl diameter (HD), hypocotyl length (HL), primary root length (PRL), hypocotyl dry mass (HDM), eophyll dry mass (EDM) and root dry mass (RDM) were determined for the normal seedlings. The experimental design was completely randomized with four replicates of 25 seeds per treatment. The data were submitted to an analysis of variance and the averages of the treatments were compared using Tukey's test at $5 \%$ probability, it was used the software Statistica 7.0 (Statsoft, 2007). 
For the morphological analysis, 30 mature, healthy, entire and non-deformed fruits were randomly selected and described in relation to fruit type, color at maturity, dimensions, texture, pericarp consistency, dehiscence, indument and number and position of the seeds inside the fruit. The observations were made visually and with the aid of a stereomicroscope. The external morphological seed parameters evaluated were the consistency and surface color of the testa, and the shape and position of the hilum, lens, micropyle and raphe. For internal observations, the tip of the seed was cut (taking care not to damage the embryo) and left in water, changed daily, for 20 days. Transversal and longitudinal sections were made with a razor blade to observe the embryo (cotyledons, hypocotyl-radicle axis and plumule) and presence, type, shape, color and location of the reserve tissue. The plumule was described based on the classification proposed by Oliveira (1999). The base of the seed was considered the part near the apex of the radicle. The biometric characteristics of the fruits and seeds were obtained by measuring the length, width, thickness and weight of 50 fruits and 50 seeds using a digital caliper (0.01 $\mathrm{mm}$ accuracy) and precision scale $(0.0001 \mathrm{~g})$.

For the morphological analyses of the post-seminal development, seeds were sown $0.5 \mathrm{~cm}$ deep in $17.5 \mathrm{~cm} \mathrm{x} 9$ $\mathrm{cm}$ x $6 \mathrm{~cm}$ Tetra Pak containers containing a substrate of sifted sand and cured sawdust (1:1), which were both sterilized. Posteriorly, ten of the most vigorous normal seedlings were used, which were obtained by direct sowing and considered in the seedling phase when they were between the emission of the primary root and the expansion of the first eophyll. The vegetative elements described and illustrated were the same as those described by Gurgel et al. (2002). The terminology used is based on works by Duke (1965, 1969), Duke \& Polhill (1981), Miquel (1987), Gunn (1991), Oliveira (1993), Spjut (1994), Barroso et al. (1999) and Ellis et al. (2009). The morphological characters of the fruits and seeds, the germination process and the seedlings were illustrated with schematic drawings and photographs.

\section{RESULTS AND DISCUSSION}

The study found significant differences among the treatments for most variables. The treatments (Table 1) with sulfuric acid, for 25 and $35 \mathrm{~min}$, and hot water promoted the initial emergence of seedlings. All the treatments were efficient in overcoming seed dormancy, except where seeds were immersed in water for 48 hours. However, for the seeds submitted to water at $70^{\circ} \mathrm{C}$, seedling emergence was markedly lower than all other treatments $(16 \%)$. In relation to emergence speed, seeds scarified with sulfuric acid for 20 and $35 \mathrm{~min}$ and those scarified in the lateral region were the best treatments. These results are similar to those encountered by Mendes et al. (2016), who analysed seeds of the same species and noted that treatments with sulfuric acid for 20 min and scarification with abrasion had the highest emergence speed.

The treatments with sulfuric acid and abrasion had the highest germination percentages (Table 2). These results were greater than those found by the following: Mendes et al. (2016), who obtained $57 \%$ and $45 \%$ seed emergence for $H$. parvifolia when treated with sulfuric acid (20 min) and mechanical scarification, respectively; and Busatto et al. (2013), with $80 \%$ and $60 \%$ emergence, Andrade et al. (2010), with $66.25 \%$ and $77.50 \%$ emergence, and Souza \& Segato (2016), with 26\% and 5\% emergence, for $H$. courbaril treated with sulfuric acid and abrasion, respectively.

The effectiveness of sulfuric acid and abrasion in overcoming the impermeability of the seed coat was also observed by several authors in other genera of Detarieae. Silva et al. (2011) observed an increase in the speed of emergence of Tamarindus indica L. seeds when they were submitted to sulfuric acid treatment for 15 minutes and obtained $65 \%$ of germinated seeds at 15 days. Oliveira $e t$ al. (2017) confirmed the efficiency of chemical and mechanical scarification for T. indica, reaching $100 \%$ and $98 \%$ of the germinated seeds at 15 days after sowing, respectively. For Copaifera langsdorffii Desf., Silva et al. (2016) reached $50 \%$ germination after scarifying the seeds for 10 minutes in sulfuric acid.

For seeds of species of Hymenaea, the efficiency of scarification with an abrasive surface for is reported by Cruz et al. (2001), who found $100 \%$ germination (26 days after the seeds were sown) for scarified seeds of $H$. intermedia. Carpanezzi \& Marques (1981) evaluated the effect of scarification on the seeds of $H$. parvifolia exposed to sulfuric acid for $35 \mathrm{~min}$ and observed around 95\% germination, which corroborates with the results obtained in the present work.

The inefficiency of hot water and immersion in water for $48 \mathrm{~h}$ can be seen by the percentages of hard seeds, which were over $50 \%$ (Table 2). The seeds scarified with hot water had a low emergence rate $(18 \%)$, a high percentage of dormant seeds $(53 \%)$ and a higher percentage of abnormal seedlings (18\%). Seeds exposed to high temperature during the scarification process may have sustained injury to the embryos. Busatto et al. (2013) submitted seeds of $H$. courbaril to water at $90{ }^{\circ} \mathrm{C}$, observed a reduction in seed germination and noted that this was probably due to the deterioration of the seeds at this temperature. Similarly, Lopes et al. (1998) found that thermal scarification of seeds of Caesalpinea ferrea Mart., Cassia grandis L. and Samanea saman Merrill. had a lethal effect on the embryos when the seeds were immersed in water at $100{ }^{\circ} \mathrm{C}$ for 30 and 60 seconds. Heat treatment 
was also not effective in breaking dormancy of seeds of C. langsdorffii (Silva et al. 2016) and T. indica (Oliveira et al. 2017), which had a low percentage of emergence or inefficiency of treatment when their seeds were subjected to water at $80^{\circ} \mathrm{C}$.
In relation to the seedling evaluation, there was a significant difference among the treatments for all variables (Table 3). The seeds scarified with sulfuric acid for $25 \mathrm{~min}$ had higher averages for all variables, except hypocotyl diameter. The superiority of this treatment can

Table 1: Days to initial seedling emergence, number of emerged seedlings and seedling emergence speed index for Hymenaea parvifolia Huber

\begin{tabular}{lccc}
\hline Treatments & ISE & ES $(\%)$ & SEI \\
\hline $\mathrm{Scar}$ in $\mathrm{H}_{2} \mathrm{SO}_{4}$ for $15 \mathrm{~min}$ & $15.5 \mathrm{bc}^{*}$ & $99 \mathrm{a}^{*}$ & $1.35 \mathrm{~b}^{*}$ \\
$\mathrm{Scar}$. $\mathrm{H}_{2} \mathrm{SO}_{4}$ for $25 \mathrm{~min}$ & $13.2 \mathrm{a}$ & $100 \mathrm{a}$ & $1.60 \mathrm{a}$ \\
$\mathrm{Scar}$ in $\mathrm{H}_{2} \mathrm{SO}_{4}$ for $35 \mathrm{~min}$ & $14.8 \mathrm{abc}$ & $95 \mathrm{a}$ & $1.40 \mathrm{ab}$ \\
$\mathrm{Scar}$ in the lateral region & $16.2 \mathrm{~cd}$ & $99 \mathrm{a}$ & $1.40 \mathrm{ab}$ \\
$\mathrm{Scar}$ in the distal region & $17.5 \mathrm{~d}$ & $96 \mathrm{a}$ & $1.03 \mathrm{c}$ \\
$\mathrm{Scar}$ in $\mathrm{H}_{2} \mathrm{O}$ at $70^{\circ} \mathrm{C}$ for $30 \mathrm{~min}$ & $14.2 \mathrm{ab}$ & $16 \mathrm{~b}$ & $0.32 \mathrm{~d}$ \\
Immersion in water for $48 \mathrm{~h}$ & - & $\mathrm{x}$ & - \\
Control & - & $\mathrm{x}$ & - \\
\hline
\end{tabular}

On what: ISE = Days to initial seedling emergence, $\mathrm{ES}=$ number of emerged seedlings and SEI $=$ seedling emergence speed index.

$(*)=$ Means followed by the same letter in the column do not differ by Tukey's test at $5 \%$ probability.

$(-)=$ Missing values.

$(\mathrm{x})$ = Values omitted from the analysis of variance are zero.

Table 2: Emergence, hard seeds, dormant seeds and abnormal seedlings for Hymenaea parvifolia Huber

\begin{tabular}{|c|c|c|c|c|}
\hline Treatments & $\mathbf{E}(\%)$ & HS & SDM & AS \\
\hline Scar. in $\mathrm{H}_{2} \mathrm{SO}_{4}$ for $15 \mathrm{~min}$ & $98 \mathrm{a}^{*}$ & $1 \mathrm{a}^{*}$ & $\mathrm{x}$ & $1 \mathrm{a}^{*}$ \\
\hline Scar. in $\mathrm{H}_{2} \mathrm{SO}_{4}$ for $25 \mathrm{~min}$ & $100 \mathrm{a}$ & $\mathrm{x}$ & $\mathrm{x}$ & $\mathrm{x}$ \\
\hline Scar. in $\mathrm{H}_{2} \mathrm{SO}_{4}$ for $35 \mathrm{~min}$ & 95 a & $3 \mathrm{a}$ & $\mathrm{x}$ & $2 \mathrm{a}$ \\
\hline Scar. in the lateral region & 97 a & $\mathrm{x}$ & $1 \mathrm{a}$ & $2 \mathrm{a}$ \\
\hline Scar. in the distal region & 96 a & $4 \mathrm{a}$ & $\mathrm{x}$ & $\mathrm{x}$ \\
\hline Scar. in $\mathrm{H}_{2} \mathrm{O}$ at $70^{\circ} \mathrm{C}$ for $30 \mathrm{~min}$ & $18 \mathrm{~b}$ & $53 \mathrm{~b}$ & $11 \mathrm{~b}$ & $18 \mathrm{~b}$ \\
\hline Immersion in water for $48 \mathrm{~h}$ & $\mathrm{x}$ & $100 \mathrm{c}$ & $\mathrm{x}$ & $\mathrm{x}$ \\
\hline Control & $\mathrm{x}$ & $100 \mathrm{c}$ & $\mathrm{x}$ & $\mathrm{x}$ \\
\hline
\end{tabular}

On what: $\mathrm{E}=$ Emergence, $\mathrm{HS}=$ hard seeds, $\mathrm{SDM}=$ dormant seeds, $\mathrm{AS}=$ abnormal seedlings.

$\left({ }^{*}\right)=$ Means followed by the same letter in the column do not differ by Tukey's test at $5 \%$ probability.

$(\mathrm{x})$ = Values omitted from the analysis of variance are zero.

Table 3: Hypocotyl diameter, hypocotyl length, primary root length, hypocotyl dry mass, eophyll dry mass and root dry mass for Hymenaea parvifolia Huber

\begin{tabular}{lcccccc}
\hline Treatments & $\begin{array}{c}\text { HD } \\
(\mathbf{m m})\end{array}$ & $\begin{array}{c}\text { HL } \\
(\mathbf{c m})\end{array}$ & $\begin{array}{c}\text { PRL } \\
(\mathbf{c m})\end{array}$ & $\begin{array}{c}\text { HDM } \\
\text { g/seedling }\end{array}$ & $\begin{array}{c}\text { EDM } \\
\text { g/seedling }\end{array}$ & $\begin{array}{c}\text { RDM } \\
\text { g/seedling }\end{array}$ \\
\hline $\mathrm{Scar}_{\text {in } \mathrm{H}_{2} \mathrm{SO}_{4} \text { for } 15 \mathrm{~min}}$ & $4.6 \mathrm{a}^{*}$ & $12.1 \mathrm{a}^{*}$ & $16.2 \mathrm{a}^{*}$ & $5.67 \mathrm{~b}^{*}$ & $5.18 \mathrm{ab}^{*}$ & $2.67 \mathrm{ab}^{*}$ \\
$\mathrm{Scar}$ in $\mathrm{H}_{2} \mathrm{SO}_{4}$ for $25 \mathrm{~min}$ & $3.6 \mathrm{~b}$ & $13.7 \mathrm{a}$ & $18.2 \mathrm{a}$ & $6.48 \mathrm{a}$ & $7.01 \mathrm{a}$ & $3.13 \mathrm{a}$ \\
$\mathrm{Scar}_{2} \mathrm{H}_{2} \mathrm{SO}_{4}$ for $35 \mathrm{~min}$ & $3.8 \mathrm{~b}$ & $12.6 \mathrm{a}$ & $15.8 \mathrm{a}$ & $6.30 \mathrm{a}$ & $5.87 \mathrm{a}$ & $2.50 \mathrm{~b}$ \\
$\mathrm{Scar}$ in the proximal region & $4.9 \mathrm{a}$ & $12.1 \mathrm{a}$ & $15.2 \mathrm{a}$ & $6.45 \mathrm{a}$ & $3.54 \mathrm{bc}$ & $2.74 \mathrm{ab}$ \\
$\mathrm{Scar}$ in the distal region & $4.8 \mathrm{a}$ & $8.8 \mathrm{~b}$ & $16.1 \mathrm{a}$ & $5.07 \mathrm{c}$ & $2.16 \mathrm{~cd}$ & $2.71 \mathrm{ab}$ \\
$\mathrm{Scar}$ in $\mathrm{H}_{2} \mathrm{O}$ at $70^{\circ} \mathrm{C}$ for 30 min & $1.02 \mathrm{c}$ & $1.2 \mathrm{c}$ & $3.5 \mathrm{~b}$ & $0.82 \mathrm{~d}$ & $0.35 \mathrm{~d}$ & $0.54 \mathrm{c}$ \\
Immersion in water for 48h & - & - & - & - & - & - \\
Control & - & - & - & - & - & - \\
\hline
\end{tabular}

On what: $\mathrm{HD}=$ Hypocotyl diameter, $\mathrm{HL}=$ hypocotyl length, $\mathrm{PRL}=$ primary root length, HDM = hypocotyl dry mass, EDM = eophyll dry mass and $\mathrm{RDM}=$ root dry mass.

$\left(^{*}\right)=$ Means followed by the same letter in the column do not differ by Tukey's test at $5 \%$ probability.

$(-)=$ Value nonexistent.

Rev. Ceres, Viçosa, v. 68, n.2, p. 105-114, mar/apr, 2021 
be explained because it had a higher emergence percentage. Souza \& Sagato (2016) analysed the vigor of $H$.courbaril seeds scarified with sulfuric acid (20 min) and with abrasion opposite the hilum. Although there was no significant difference between the treatments, they observed that the chemically scarified seeds were less vigorous than those mechanically scarified. They also noted that absorption of the acid by seeds during the chemical treatment could have caused the lower vigor. In the present study, this was not observed since the seeds scarified with acid for 25 min were the most vigorous.

Fruit is a camara (Figure 1A, B), indehiscent, dry, ovoid; stipe inserted into the remnants of the uniseriate calyx (Figure 1D), margins not constricted, pedicel terete, woody, dark greyish brown, opaque, rugose, striate, glabrous ( $\mathrm{Fi}$ gure 1C). Exocarp is a lighter brown, homochromous, glabrous, chartaceous, resinous; endocarp is fibrousspongy, yellowish brown, opaque, glabrous, Funicle is chartaceous. A globose camara, with an external woody layer and yellowish brown, velvety, farinaceous and fibrous pulp, was observed by Camargo et al. (2008) for the same species. These characteristics are similar to those encountered by Duarte et al. (2016) for $H$. courbaril. These authors observed a dry, indehiscent, polyspermous fruit with a thick mesocarp and thin, soft, spongy endocarp. Sousa et al. (2010) observed in T. indica, dry, indehiscent and polyspermic fruit, differed from the species under study, the crustacean epicarp, pulpy-gelatinous mesocarp and the epicarp detached from the seed.

Barroso et al. (1999) noted that the seeds of Hymenaea have a fleshy funiculus that is surrounded by a white aril. However, Gunn (1991) points out that the seeds of the genus do not have an aril and described this structure as the endocarp, which was corroborated by Paiva \& Oliveira (2004) and adopted in the present work. The presence of aryl is a variable character among species belonging to the genera of Detarieae. Guibourtia hymenifolia (Moric.) J. Léonard presented spongy and whitish aryl (Battilani
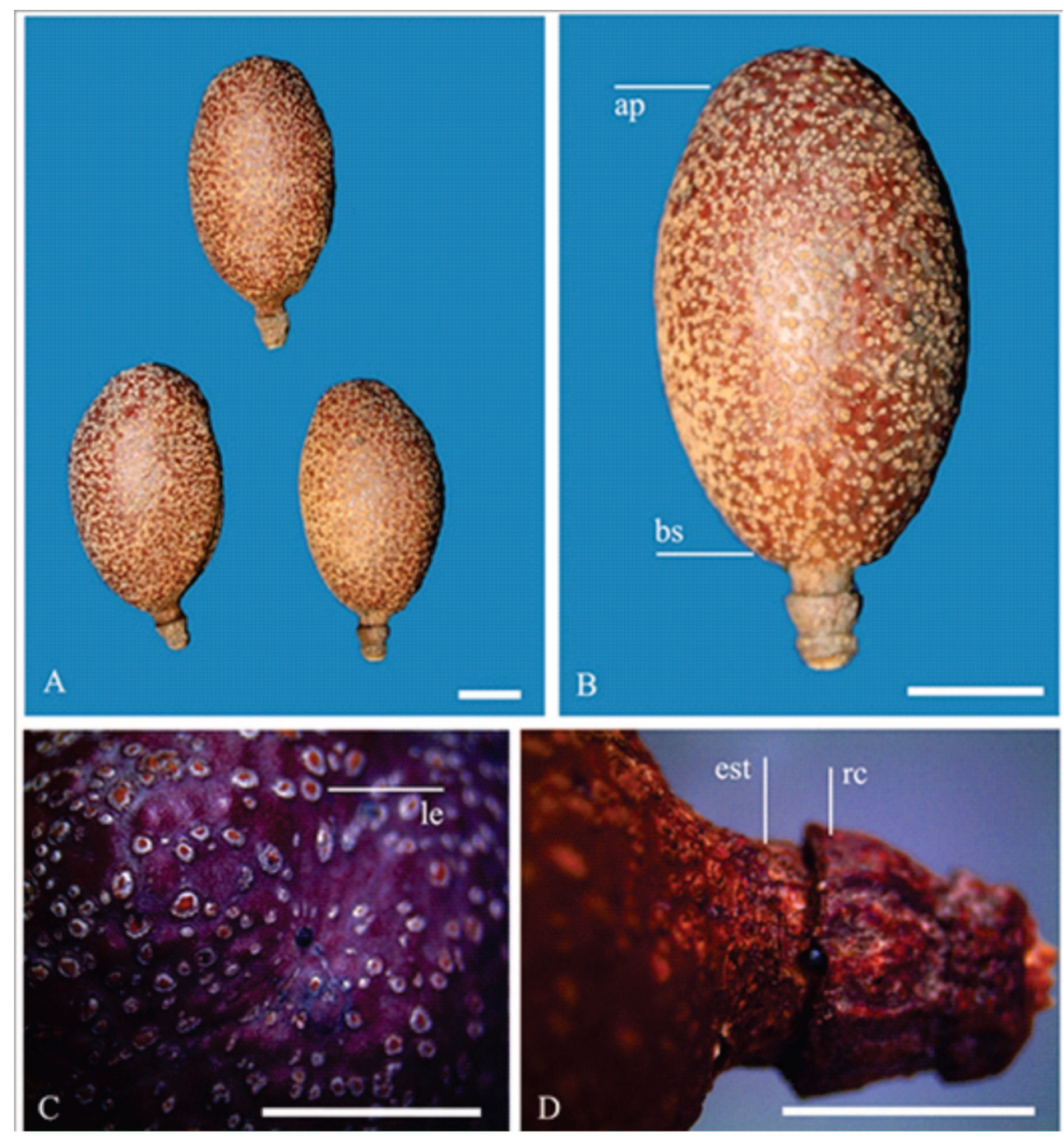

Figure 1: Fruit of Hymenaea parvifolia Huber A) Camara; B) entire fruit; C) lenticels in detail; D) base of camara. Legend: ap - apex, bs - base, est - stipe, le - lenticels, rc - remnants of calyx. Scale: A and B) $1 \mathrm{~cm}$; C and D) $0.5 \mathrm{~cm}$. 
et al., 2011), Guibourtia chodatiana (Hassl.) J.Léonard the aryl is white and covers the entire seed (Pinto et al., 2017), Copaifera arenicola [(DUCKE) J. COSTAAND LP QUEIROZ] the aryl is yellow (Gama \& Nascimento Jr, 2019) and C. langsdorffii the aryl is orange (Souza et al., 2017). For T. indica, the aryl is present in a small amount around the seeds (Sousa et al., 2010).

The seeds of $H$. parvifolia are oblong and highly uniform in both shape and size (Figure 2A). The testa is homochromous, rocklike, dark brown, opaque, smooth (Figure 2B), completely surrounded by a farinose, greyishwhite endocarp, pleurogram absent.The hilar region is basal (Figure 2C), near the apex of the radicle, hilum is punctiform and lens is more prominently rounded, opaque, reticulate, glabrous, imperceptible to the naked eye. Micropyle and raphe are imperceptible. Embryo is cotyledonar and axial, plumule is moderately developed or poorly differentiated (mitaforme type), in the form of a glove (Figure 2D, E). Camargo et al. (2008) described the seeds of $H$. parvifolia as ellipsoid with a smooth and glabrous testa, punctate hilum and pleurogram absent. In $H$. courbaril the seeds presents the following characteristics: tegument stony, reddish to dark brown; hilumoblong, micropyle discreet, embryo axial, cotyledonar differing from $H$. parvifolia by the ovoid and globular shape (Duarte et al., 2016). These characteristics corroborate the circumscription of the genus. However, some characteristics such as: dark brown forehead, hilum punctiform, crass cotyledons and axial embryo are common to T. indica, which differ from the species under study, due to the presence of a pleurogram on both sides, a plumule with bifoliolated rudiments and the hypocotyl axis, radicle of the asciform type (Sousa et al., 2010).

Germination is phanerocotyledonar, epigeous, and emergence is curved and then straight. Similar features were described by Guerra et al. (2006) para C. Langsdorffii, Kadoma \& Sartori (2007) for seedlings of Hymenaea stilocarpa var. stilocarpa Mart., Camargo et al. (2008) for H. parvifolia, Sousa et al. (2010) para T. indica, Battilani et al. (2011) para G. hymenifolia and Duarte et al. (2016) for $H$. courbaril.In the present study, the hydrated seeds increased in volume and on the ninth day after sowing the main root broke the seed coat in the basal region (Figure 3A). The main root is yellowish, glabrous, root cap is not evident, root collar is asymmetrically differentiated, pinkish, with hairs numerous, simple, hyaline, long, straight, with curved, adpressed apex (Figure 3B), lenticels are reddish brown. Cotyledons are oblong, thick, reddish,
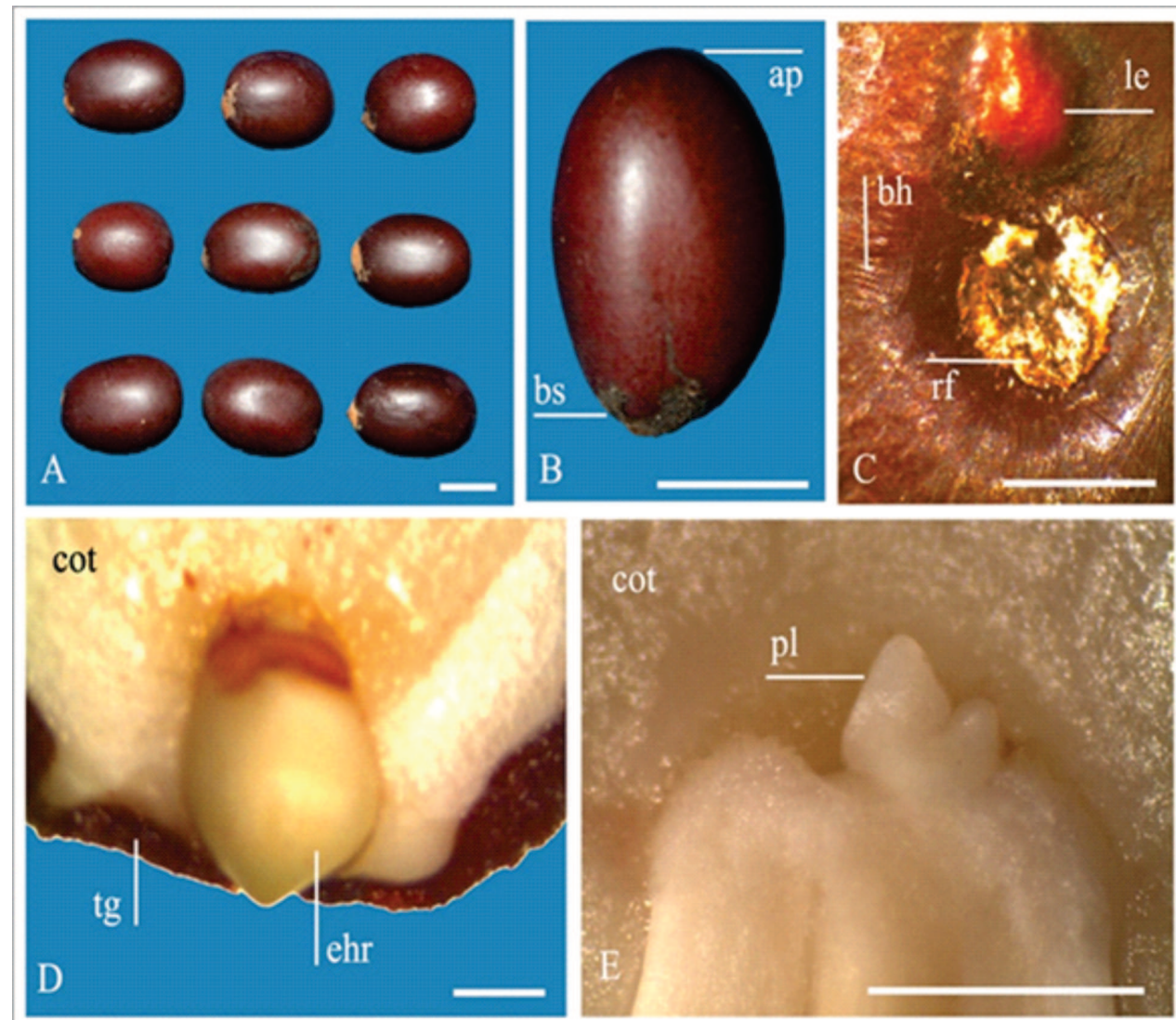

Figure 2: Seeds of Hymenaea parvifolia Huber A) oblong seeds; B) apex and base; C) hilar region in detail; D) embryonic axis; E) mitaformplumule. Legend: ap - apex, bh - hilar border, bs - base, cot - cotyledons, ehr - hypocotyl-radicle axis, le - lens, pl - plumule, tg - tegmument, rf - funicular remnants. Scale: A) $1 \mathrm{~cm}$; B) $0.5 \mathrm{~cm}$; C and E) $1 \mathrm{~mm}$. 
parallel and unilateral, opposite when completely open, sessile, trichomes are rare, simple, hyaline, reduced on the margins and adaxial surface. $H$. courbaril emits the main root on the third day after sowing, with similar characteristics to those described in this study, they differ by the little differentiated neck (Duarte et al., 2016).

Roots are pivotal, the main root is axial, cylindrical, sinuous, subwoody, rarely with hairs that are simple, hyaline, reduced and straight, streaks and lenticels are dark brown, and side roots are numerous (Figure 3D). Hypocotyl and root collar are also elongate, which is similar to what was observed by Melo et al. (2004) in a study of $H$. intermedia seedlings. Root collar is evident, asymmetrical, reddish, hairs are numerous, simple, hyaline and short, posteriorly unilateral (Figures 3E; 4A). Hypocotyl is vigorous, epigeous, straight, rectangular with rounded vertices, reddish, subsequently turning ferruginous, with many simple trichomes that are hyaline, short and straight, lenticels are present, reddish and intact (Figures 3F; 4B, C). These characteristics confirm the descriptions made by Camargo et al. (2008) for the same species, observed the elongated hypocotyl, initially pink, becoming brown, initially smooth, becoming striated and covered by short whitish hairs. The morphology of the $H$. parvifolia hypocotyl differs of $H$. intermedia var. adenotricha that has a cylindrical shape and a light green color (Melo et al., 2004), from T. indica with a cylindrical, light green and glabrous shape (Sousa et al., 2010).

Cotyledons are fleshy, pinkish, elliptical, initially covered by the seed coat and rarely with trichomes around them (Figure 3E, F). This differs from what was encountered by Kadoma \& Sartori (2007) for seedlings of H.coubaril, which lacked the trichomes and elliptical shape of the cotyledons. Epicotyl was straight, cylindrical, greenish, glabrous, with light brown lenticels, a bud in development and a stipule (Figures 3G; 4D, E, F, I). These characteristics corroborate with Duarte et al. (2016) who described the $H$. courbaril epicotyl as long, green with the presence of stipules in the first two metaphiles.Eophylls were simple, unifoliolate, reddish brown, opposite, ovoid, apex obtuse, margin ciliate, rarely with simple, hyaline, reduced, straight trichomes, base reniform, venation penninerved, secondary veins eucaptodromous, tertiary veins reticulate, immersed on the adaxial surface, impressed on the abaxial surface, coriaceous, translucent glands throughout the laminar surface;pulvinus and pulvinule green, striated, rugose, short, both with simple, hyaline trichomes (Figure 4D), the pulvinule more frequently lateral (Figures 3G; 4G, H, I). The characteristics of pulvino and pulvino were similar to those described by Melo et al. (2004) for the eofilos of $H$. intermedia that differ from $H$. parvifolia by their light green color and for being composed.

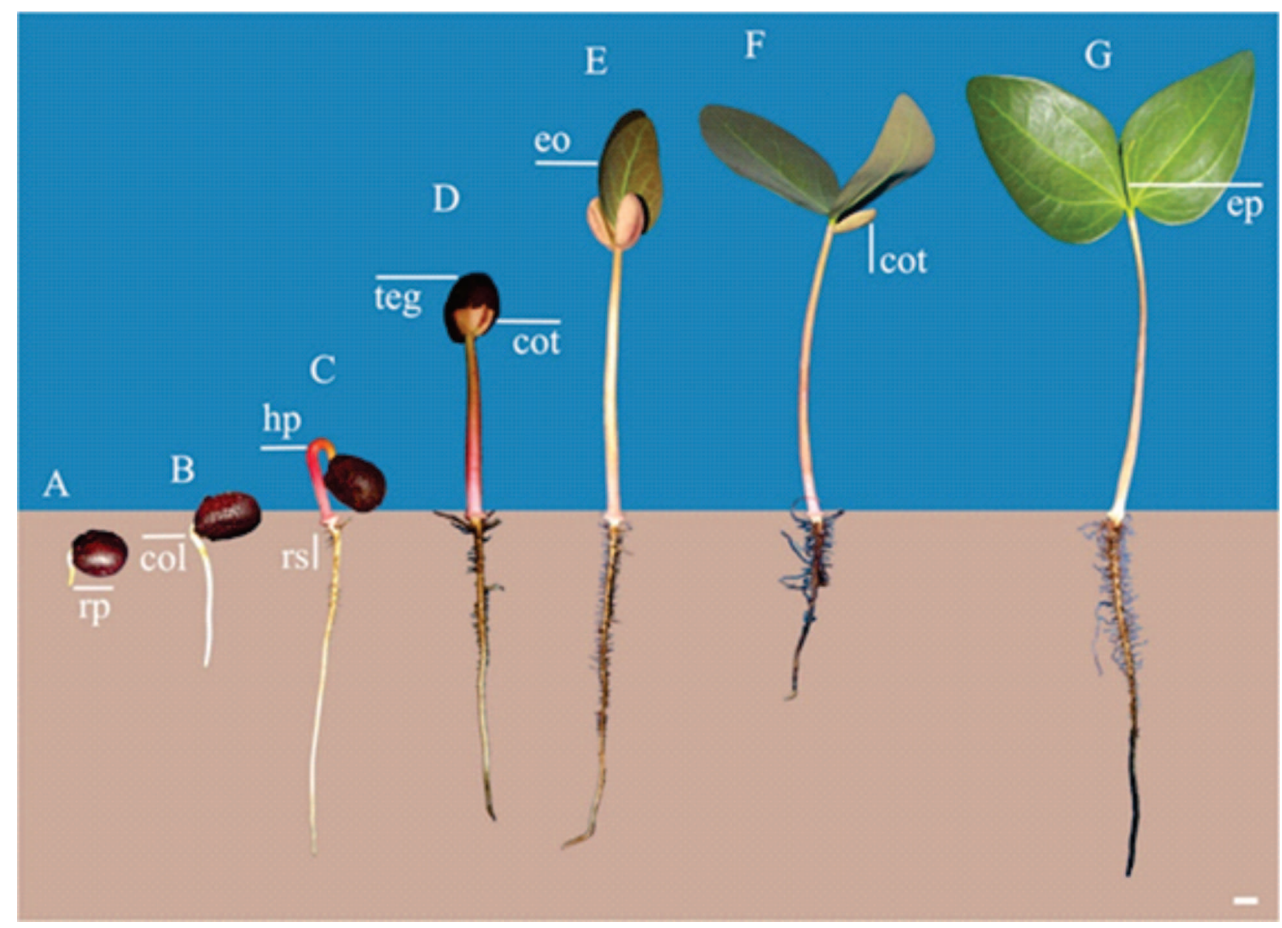

Figure 3: Stages of post-seminal development and seedlings of Hymenaea parvifolia Huber A) primary root emission; B) elongated primary root; C) hypocotyl handles; D) straight hypocotyl; E) emergence of eophylls; F) free and fully expanded eophylls from cotyledons; G) elongated epicotyl. Legend: col - differentiated root collar, hp - hypocotyl, rs - secondary roots, teg - tegument; cot - cotyledons, eo - eophylls, ep - epicotyl, rp - primary root. Scale: $1 \mathrm{~cm}$. 

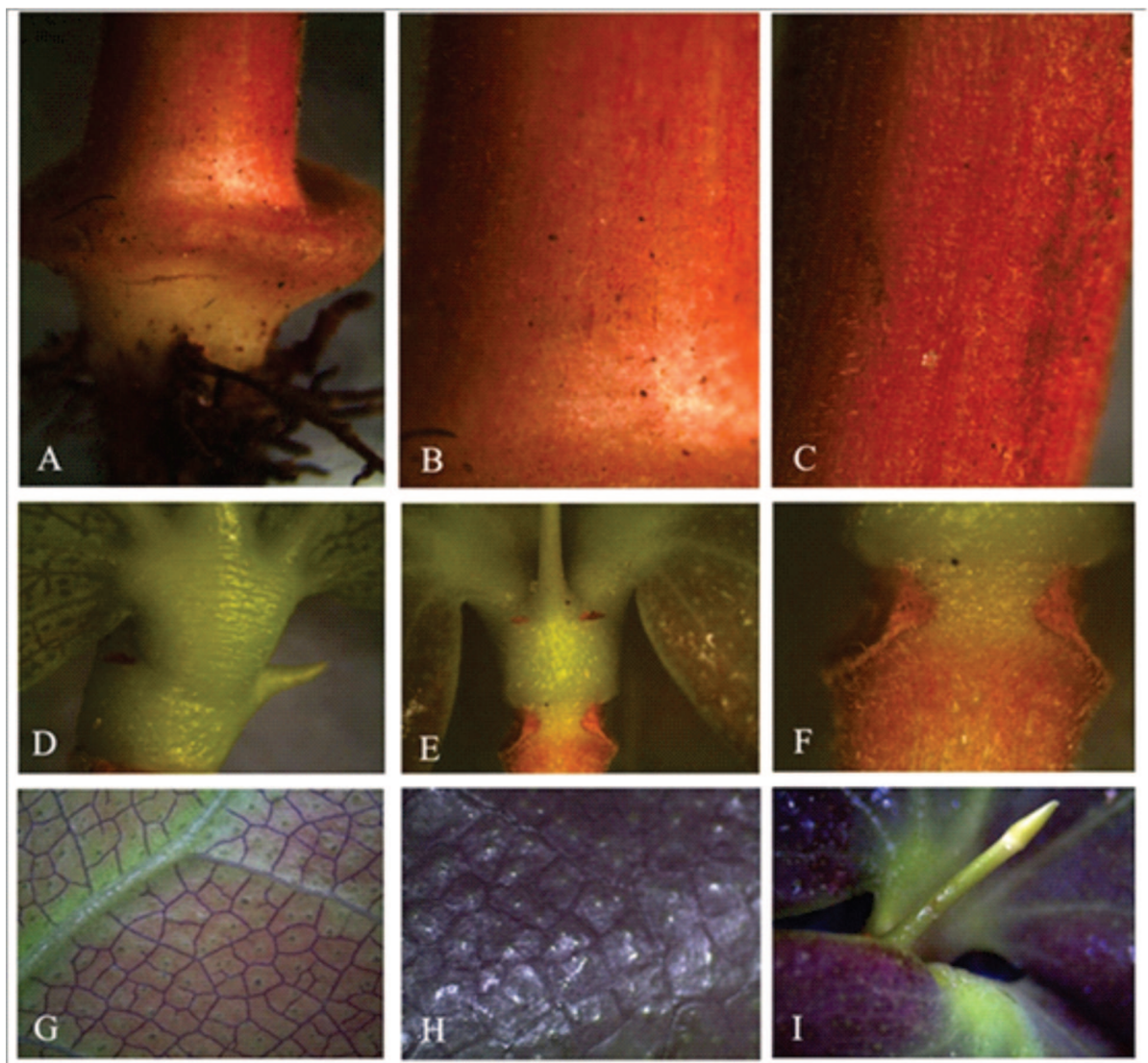

Figure 4: Details of the seedling of Hymenaea parvifolia Huber A) Root collar; B) Hypocotyl marks; C) hyaline trichomes on the hypocotyl; D) striate pulvinus and pulvinule; E) sessile eophylls and stipule scar; F) Cotyledon scars; G) Glands on the abaxialeophyll lamina; H) Glands on the adaxialeophyll lamina; I) Epicotyl. Magnification: 25x.

\section{CONCLUSIONS}

The treatments used in this study to break the dormancy of $H$. parvifolia Huber can make a difference in seed germination time and seedling vigor. Thus, treatments based on sulfuric acid for 15, 25 and 35 minutes were the most efficient in overcoming the integumentary dormancy and better in all aspects analysed. However, scarification by grinding the side near the hilum is recommended because it has less impact on the environment.

Morphological characteristics of fruits, seeds, postseminal development and seedlings highlighted here have been shown to be a useful resource for the differentiation between this and other species of Hymenaea. Among them, those characteristics with higher taxonomic value are the fruit shape of Hymenaea parvifolia, size and shape of the seed and characteristics of the epicotyl.

\section{ACKNOWLEDGEMENTS, FINANCIAL SUPPORT AND FULL DISCLOSURE}

We thank the Museu Paraense Emílio Goeldi and the Universidade Federal Rural da Amazônia for the academic support, Embrapa Amazônia Oriental for the equipment and loans.
This work was carried out with support financial from the National Council for Scientific and Technological Development - CNPq.

There is no conflict of interest in the conduct and publication of this work.

\section{REFERENCES}

Almeida MB, Souza WCO, Gomes ECS \& Villar FCR (2011) Descrição morfológica do fruto e semente do Jatobá (Hymenaea courbaril L.). Revista Semiárido de Visu, 01:107-115.

Andrade AA, Bruno RLA, Oliveira LSBO \& Silva HTF (2010) Aspectos biométricos de frutos e sementes, grau de umidade e superação de dormência de jatobá. Acta Scientiarum Agronomy, 32:293-299.

Azeredo GA, Bruno RLA, Andrade LA \& Cunha AO (2003) Germinação em sementes de espécies florestais da Mata Atlântica (Leguminosae) sob condições de casa de vegetação. Pesquisa Agropecuária Tropical, 33:11-16.

Barroso GM, Amorim MP, Peixoto AL \& Ichaso CLF (1999) Frutos e sementes: Morfologia aplicada à sistemática de dicotiledôneas. $1^{\text {st }}$ ed. Viçosa, Editora UFV. 444p.

Battilani JL, Santiago EF \& Dias ES (2011) Morfologia de frutos, sementes, plântulas e plantas jovens de Guibourtia hymenifolia (MORIC.) J. LEONARD (Fabaceae). Revista Árvore, 35:10891098. 
Bentes-Gama MM, Pereira NS, Capelasso PHS, Salman AKD \& Vieira AH (2008) Espécies arbóreas com potencial para recuperação de paisagens alteradas em Rondônia. Porto Velho, Embrapa Rodônia. 29p.

Botelho SA, Ferreira RA, Malavasi MM \& Davide AC (2000) Aspectos morfológicos de frutos, sementes, plântulas e mudas de jatobá-do-cerrado (Hymenaea stignocarpa Mart. ex Hayne) - Fabaceae. Revista Brasileira de Sementes, 22:144152.

Brasil (2009) Regras para Análise de Sementes. $1^{\text {st }}$ ed. Brasília, Ministério da Agricultura, Pecuária e Abastecimento. 398p.

Busatto PC, Nunes AS, Colman BA \& Masson GL (2013) Superação de dormência em sementes de jatobá (Hymenaea courbaril L.). Revista Verde, 08:154-160.

Camargo JLC, Ferraz IDK, Mesquita MR, Santos BL \& Brum HD (2008) Guia de propágulos e plântulas da Amazônia. $1^{\text {st }}$ ed. Manaus, Editora INPA. 168p.

Carpanezzi AA \& Marques LCT (1981) Germinação de sementes de jutaí-açu (Hymenaea courbaril L.) e de jutaí-mirim (Hymenaea parvifolia Huber) escarificadas com ácido sulfúrico comercial. Belém, Embrapa/Centro de Pesquisa Agropecuária do Trópico Úmido. 15p. (Circular, 19).

Cruz ED, Martins FO \& Carvalho JEU de (2001) Biometria de frutos e sementes e germinação de jatobá-curuba (Hymenaea intermedia Ducke, Leguminosae- Caesalpinioideae). Revista Brasileira de Botânica, 24:161-165.

Duarte MM, Paula SRP, Ferreira FRL \& Nogueira AC (2016) Morphological characterization of fruit, seed and seedling and germination of Hymenaea courbaril L. (Fabaceae) ('Jatobá'). Journal of Seed Science, 38:204-211.

Duke JA (1969) On tropical tree seedlings I. Seeds, seedlings, systems and systematics. Annals of the Missouri Botanical Garden, 56:125-161.

Duke JA (1965) Keys for the identification of seedlings of some proeminent woody species in eight forest types in Puerto Rico. Annals of the Missouri Botanical Garden, 52:314-350.

Duke JA \& Polhill RM (1981) Seedlings of Leguminosae. In: Polhill RM \& Raven PH (Eds.) Advances in Legumes Systematics. Kew, Royal Botanical Garden. p.941-949.

Ellis B, Daly DC, Hickey LJ, Mitchell KRJJD \& Wing PWSL (2009) Manual of leaf architecture. Ithaca, Cornel University Press. 200p.

Fowler AJP \& Bianchetti A (2000) Dormência em sementes florestais. Colombo, Embrapa Florestas. 27p.

Gama DC \& Nascimento Júnior JM (2019) Copaifera arenicola [(DUCKE) J COSTA ELP QUEIROZ] Fabaceae Caesalpinioideae em Regióes do Nordeste da Bahia. Agroforestalis News, 4:i-viii.

Guerra MEC, Medeiros Filho S \& Gallão MI (2006) Morfologia de sementes, de plântulas e da germinação de. Copaifera langsdorfii Desf. (Leguminosae-Caesalpinioideae). Cerne, 12:322-328.

Gunn CR (1991) Fruits and seeds of genera in the subfamily Caesalpinioideae (Fabaceae). Springfield, Agricultural Research Service. 408p. (Technical Bulletin, 1755).

Gurgel ESC, Silva MF \& Carreira LM (2002) Morfologia do fruto, semente, germinação e da plântula de Calopogonium mucunoides Desv. e Dipteryx odorata (Aubl.) Willd. (Leguminosae - Papilionoideae). Botânica, 18:35-59.

Gurgel ESC, Santos JUM dos, Barata FCA \& Bastos M (2012) Morfologia de plântulas de Leguminosae e o potencial sistemático. Rodriguésia, 63:65-73.
Kadoma MT \& Sartori ALB (2007) Caracterização morfológica de plântulas de Hymenaea stilocarpa var. stilocarpa Mart. ex Hayne, H. stilocarpa Hayne var. brevipetiolata N. Mattos e $H$. Courbaril L. Revista Brasileira de Biociências, 05:663-665.

Langenheim JH \& Lee YT (1974). Reinstatement of the genus Hymenaea (Leguminosae: Caesalpinioideae) in Africa. Brittonia, 26:3-21.

Azani N, Babineau M, Bailey CD, Banks H, Barbosa AR, Pinto RB, Boatwright JS, Borges LM, Brown GK, Bruneau A, Candido E, Cardoso D, Chung KF, Clark RP, Conceição ADS, Crisp M, Cubas P, Delgado-Salinas A, Dexter KG, Doyle JJ, Duminil J, Egan AN, De LEM, Falcão MJ, Filatov DA, Fortuna-Perez AP, Fortunato RH, Gagnon E, Gasson P, Rando JG, Tozzi, Ana Maria GA, Gunn B, Harris D, Haston E, Hawkins JA, Herendeen PS, Hughes CE, Iganci JRV, Javadi F, Kanu SA, KazempourOsaloo S, Kite GC, Klitgaard BB, Kochanovski FJ, Koenen EJM, Kovar L, Lavin M, Roux ML, Lewis GP \& De LHC (2017) A new subfamily classification of the leguminosae based on a taxonomically comprehensive phylogeny: The Legume Phylogeny Working Group (LPWG). Taxon, 66: 44-77.

Lopes JC, Capucho MT, Kroohling B \& Zanotti P (1998) Germinação de sementes de espécies florestais de Caesalpinea ferrea Mart. ex Tul var. leiostachya Benth., Cassia grandis L. e Samanea saman Merrill., após tratamentos para superar a dormência. Revista Brasileira de Sementes, 20:80-86.

Maguire JD (1962) Speed of germination-aid in selection evaluation for seedling emergence and vigor. Crop Science, 01:176-177.

Maranho AS, Paiva AV \& Paula SRP (2013) Crescimento inicial de espécies nativas com potencial madeireiro na Amazônia, Brasil. Revista Árvore, 37:913-921.

Melo MGG, Mendonça MS \& Mendes AMS (2004) Análise morfológica de sementes, germinação e plântulas de jatobá (Hymenaea intermédia Ducke var. adenotricha (Ducke) Lee \& Lang.) (Leguminosae - Caesalpinioideae). Acta Amazonica, 34:09-14

Mendes CS, Costa FN, Lima LSA, Carvalho JC \& Reis ARS (2016) Superação de dormência em sementes de jutaí-mirim (Hymenaea parvifolia Huber). Biota Amazônia, 06:12-16.

Miquel S (1987) Morphologiefonctionelle de plantules d'especes forestières Du Gabon. Bulletin Muséum National d'Histoire Naturelle, Adansonia Botanique Phytochimie, 09:101-121

Miranda EM \& Valentim JF (2000) Desempenho de doze espécies arbóreas nativas e introduzidas com potencial de uso múltiplo no Estado do Acre, Brasil. Acta Amazonica, 30:471-480.

Oliveira DMT (1999) Morfo-anatomia do embrião de leguminosas arbóreas nativas. Revista Brasileira de Botânica, 22:413-427.

Oliveira DMT (2001) Morfologia comparada de plântulas e plantas jovens de leguminosas arbóreas nativas: espécies de Phaseoleae, Sophoreae, Swartzieae e Thephrosieae. Revista Brasileira de Botânica, 24:85-97.

Oliveira EC (1993) Morfologia de plântulas florestais. In: Aguiar IB, Piña-Rodrigues FCM \& Figliola MB (Eds.) Sementes Florestais Tropicais. Brasília, ABRATES. p.175-214.

Oliveira EP, Oliveira EP, Costa CB, Santos GMSS \& Guariz HR (2017) Superação de dormência em sementes de Tamarindus indica L. submetidas a diferentes tratamentos pré-germinativos. Revista Científica Eletrônica de Agronomia, 32.

Paiva EAS \& Oliveira DMT (2004) Ontogenesis of the fruit pulp layer of Hymenaea stigonocarpa: (Fabaceae - Caesalpinioideae). Australian Journal of Botany, 52:677-683.

Pinto RB, Mansano VF, Sartori ALB \& Tozzi AMGA (2017) Revisiting the taxonomic diversity of Guibourtia in the neotropics (Leguminosae, Detarioideae). Phytotaxa, 327:130-140. 
Pinto RB, Tozzi AMGA \& Mansano VF (2018) Hymenaea in Flora do Brasil 2020 em construção. Available at: http:// floradobrasil.jbrj.gov.br/reflora/floradobrasil/FB22976. Accessed on: November $28^{\text {th }}, 2018$.

Shanley P \& Rosa NA (2004) Eroding knowledge: an ethnobotanical inventory in eastern Amazonia's logging frontier. Economic Botany, 58:135-160.

Silva BPD, Barros GL, Almeida JPN, Procópio IJS \& Medeiros PVQ (2011) Tempo de germinação e desenvolvimento inicial na produção de mudas Tamarindus indica L. Revista Verde, 6:58-56.

Silva CA, Teixeira AL, Gomes RLA, Marques FRO, Silva AAS \& Silva ACA (2016) Effects of pre-germination treatments on Copaifera langsdorffii seeds. African Journal of Agricultural Research, 11:4027-4030.

Silva BHS, Lima JD, Dantas VAV, Moraes WS \& Sabonaro DZ (2007) Efeito da luz no crescimento de mudas de Hymenaea parfivolia Huber. Revista Árvore, 31:1019-1026.
Sousa DMM, Alcântara Bruno RDL, Dornelas CSM, Alves EU, Andrade APD \& Nascimento LC (2010) Caracterização morfológica de frutos e sementes e desenvolvimento pós-seminal de Tamarindus indica L. Revista Árvore, 34:1009-1015.

Souza AO, Silva MJ \& Dantas MM (2017) Os gêneros Apuleia, Dimorphandra, Tachigali (Caesalpinioideae), Bauhinia, Schnella (Cercidoideae), Copaifera, Hymenaea e Peltogyne (Detarioideae) (Leguminosae) no Parque Estadual da Serra Dourada, Goiás, Brasil. Rodriguésia, 68:1273-1286.

Souza VMS \& Segato SV (2016) Superação de dormência em sementes de jatobá (Hymenaea courbaril L.). Nucleus, 13:1.

Spjut RW (1994) A systematic treatment of fruit types. New York, Memoirs of the New York Botanical Garden. 182p.

StatSoft Inc. (2007) Statistica for Windows: data analysis software system. Version 7.0. Tulsa, StatSoft.

Tonini H, Oliveira Junior MMC \& Schwengber D (2008) Crescimento de espécies nativas da Amazônia submetidas ao plantio no Estado de Roraima. Ciência Florestal, 18:151-158. 